УДК 821.161. 2 - 343-344’06

Кизилова Віталіна, доктор філологічних наук, професор, професор кафедри філологічних дисциплін ДЗ «Луганський національний університет імені Тараса Шевченка» (м. Старобільськ)

\title{
КОНОТАТИВНІ ВИМІРИ МОТИВІВ УКРАЇНСЬКОЇ ЛІТЕРАТУРНОЇ КАЗКИ
}

У статті висвітлено проблему мотиву літературної казки. Звернено увагу на особливості застосування в авторському тексті фольклорного первня, його "осучасненні" залежно від конщепиії твору, світоглядних уподобань, соціокультурного контексту доби. На прикладі мотивів сну $i$ дзеркала украӥнської літературної казки другої половини ХX початку XXI cm. продемонстровано семантичну спорідненість, розглянуто конотативні можливості, продуктивність щчодо репрезентації авторського ставлення до світу. $У$ казковому літературному творі мотиви стають актуалізатором його глибинної структури, посилюють символічний зміст, забезпечують кількаплощинність тексту.

Ключові слова: літературна казка, фольклор, мотив, сюжет, автор, сон, дзеркало.

\section{Kyzylova $\boldsymbol{V}$. Connotative dimensions of the motives in Ukrainian literary tale.}

The article presents the problem of a fairy tale's motive. The attention is drawn to the use of folkloric basis in the author's text, its “modernity", dependent on the work's conception, outlook preferences and social cultural context. With the help of the examples of motives of dream and 
mirror in the Ukrainian literary tales of the second half of XX-beginning of XXI centuries semantic similarity is shown, connotative opportunities are discussed as well as productivity, connected with representation of the author's outlook. In a fairy literary tale motives become an actualizer of its deep structure, they strengthen symbolic context, provide with several dimensions of the text.

Key words: literary tale, folklore, motive, plot, author, dream, mirror.

Важливе місце в поетикальній системі авторського твору посідає мотив одиниця сюжету, що розглядається в аспекті іï повторюваності, типовості, тобто така, що має значення або традиційне (відоме фольклору, літературі, жанру), або притаманна творчості того чи того письменника і навіть окремого твору [1, с. 194]. Науковці (А. Бем, Е. Мелетинський, Н. Тамарченко, О. Фрейденберг) мовлять про мотиви, притаманні певному типу літературного твору: ліричні мотиви (напр., наближення осені, мінливість життя), епічні мотиви (вбивство, помста), драматичні мотиви (ворожнеча, помста), мотиви циклу творів (як ланцюг їх побудови), індивідуальні письменницькі мотиви тощо.

Фольклорні казкові тексти мають набір стійких сюжетних мотивів. Так, у чарівних казках - це мотиви подорожі, перетворення, властивості чудодійних предметів, у соціально-побутових - протистояння багатого й бідного, мачухи й пасербиці, суперництво братів, у казках про тварин - вигнання в чужий простір, трапезування, одруження та ін. Детальніше про це: [2; 3].

В. Пропп мотиви чарівної казки розглянув на прикладі функцій героя (ïх 31), що групуються навколо незмінних сюжетних вузлів: відправка, переправа, поєдинок i перемога, повернення, шлюб. На думку вченого, ці основні мотиви утворюють єдину композицію сюжету (сюжетну схему), котра в кожному окремому випадку конкретизована певними мотивами: напр., переправа - політ на килимі-літаку, спуск у колодязь, вхід всередину гори тощо $[4$, c. 125$]$.

На думку О. Веселовського, мотиви мають історичну стабільність й водночас здатність до повторюваності. Дослідник припускав, що кожна нова поетична епоха працює над вже відомими, заповіданими історією образами, обертається в їх межах, дозволяючи нові комбінації старих та наповнюючи їх 
новим розумінням життя $[5$, с. 301$]$. Слушність його думки підтверджується численними прикладами 3 літературної казки, яка, вибудовуючи цілісний художній світ, апелювала до фольклорних пратекстів, репрезентувала нові семантичні можливості мотивів та сюжетів.

Так, повість-казка «В Країні Сонячних Зайчиків» В. Нестайка позначена мотивами подорожі в «інший» світ, випробування, подолання перешкод. Мотив чарівної дитини рухає сюжет казок Вал. Шевчука «Бігунець та Котило», Зірки Мензатюк «День, що не має кінця», Ігоря Калинця «Вертеп Маленького Хлопчика», В. Нестайка «В Країні Сонячних Зайчиків». Мотив чарівного засобу, за допомогою якого відбувається казкова дія, лежить в основі казок 3. Мензатюк «Арніка» (цілюща вода), Ю. Ярмиша «Паличка-рятівниця» (чарівна паличка), М. Павленко «Удова й два сини» (чарівний клубочок), I. Жиленко «Новорічна історія про двері, яких нема, і про те, як іноді корисно помилятися номером» (чарівне дзеркало). Мотив освоєння тваринами простору засобами кумуляції притаманний казкам Л. Храпливої-Щур «Великодня пригода», Л. Письменної «Зозуля, що мала гніздо», Ю. Ярмиша «Хто-хто в теремкові живе» тощо.

Варто відзначити, що в художньому просторі авторської казки письменник здебільшого фольклорний первінь модифікує, «осучаснює», привносить своє бачення розгортання подій залежно від концепції твору, світоглядних уподобань, соціокультурного контексту доби тощо. Наприклад, мотив незвичайної країни у повісті-казці В. Нестайка - це мрія маленького веснянкуватого хлопчика, Веснянки, його уява, фантазія. Казкова країна дарує хлопчикові-сироті надію на примирення його внутрішнього й зовнішнього стану, сподівання жити у світі, позбавленому небажаних, жорстоких явищ, притаманних земній реальності. Автор зображує іiі яскравими, соковитими барвами. У ній панує гармонія: усюди можна зустріти лише добрих усміхнених героїв, а найкращими ліками від усіх хвороб є сміх.

У трилогії «Країна Сонячних Зайчиків» В. Нестайко апелює до мотиву лicy, що мігрував із фольклорних джерел. У першій частині - це тропічний ліс - 
місце створення колонії «Притулок маленьких друзів», у «Чарівному дзеркальці...» (2-га частина) він - умовний кордон реального й ірреального світів, у третій частині («В Країні Місячних Зайчиків») ліс - місце скупчення негативних сил, вороже середовище, хтонічний вимір. Він ворожий, «...темний, таємничий, дещ̧о умовний, не зовсім реалістичний» [6, с. 151]. Ліс у «Країні Місячних Зайчиків» набуває ще й метафоричного значення; він асоціюється 3 моделлю світу, що відображає процес становлення стійких цінностей буття. Символічним виступає і процес «лікування» лісу гномом Цибулькою - як своєрідний обряд очищення соціуму від усього застарілого, відродження у процесі ініціації.

Досліджуючи семантику мотиву твору, науковці звертають увагу на особливий спосіб його ідентифікації через ключовий іменник, пов’язаний із відповідним дієсловом прямими словотвірними стосунками: мотив зради, мотив зустрічі, мотив подорожі тощо [7, с. 14].

С. Золян вказує на семантичну спорідненість мотивів сну і дзеркала, адже вони відображають актуальний світ в іншому часі - минулому чи майбутньому, репрезентують істинну сутність індивіда в іншому світі [8, с. 36]. Цікаво спостерегти конотативні можливості цих мотивів на прикладі української літературної казки другої половини XX - початку XXI століття, що становить мету даної розвідки.

Мотив дзеркала у жанрі казки досить поширений («Білосніжка та семеро гномів» братів Грім, «Снігова королева» Г. К. Андерсена, «Казка про мертву царівну та семи богатирів» О. Пушкіна, «Аліса в задзеркаллі» Л. Керолла). У повісті-казці В. Нестайка «В Країні Сонячних Зайчиків» дзеркало стає межею між світами: «-Ну, от ми й прибули, - сказав пан Морок. - По той бік цุього чарівного дзеркала - Краӥна Сонячних Зайчиків. Ми повинні пройти $m y \partial u \ldots »[6$, c. 43].

Своїми витоками цей мотив сягає міфології й фольклору, де дзеркало було наділене магічними властивостями: «Ще в міфологічній свідомості феномен „дзеркальності” пов'язувався з візуальним сприйняттям, пізнанням 
навколишнього світу, баченням віддалених у просторі та часі реальних об'єктів (тобто з „тут-буттям”), а також - зі світом потойбічним, чужим, влаштованим протилежним чином (,там-буттям”). Протягом подальщої історії художньої творчості „дзеркало” викристалізовується в полівалентний символ, щзо вбирає до себе широку гаму людських уявлень про світ: як світ реальний в усьому його розмайтті, так і світ ідеальний, трансиендентний» [9].

Таким ідеальним світом у творі постає Країна Сонячних Зайчиків, зображена автором як величезний квітник: «Bci квіти, які тільки $\epsilon$ в природі, квітували тут одночасно. Стрункі гордовиті іриси ци сором'язлива матіола [...]. Самозакохані наричиси та скромні чорнобривціi. Розкішні ясночервоні канни і непомітна кімнатна примула. [...] виструнчилися рожі, лілеї, троянди, гладіолуси, жоржини» [6, с. 57].

У «Незнайомці з Країни Сонячних Зайчиків» автор апелює до чарівного дзеркальця, поглянувши в яке, однокласники Васі, головного героя твору, зможуть побачити свою істинну сутність: «Воно не тільки тому чарівне, щзо пускає чарівного сонячного зайчика: кожен, хто погляне у нього, ніби зазирне собі у душу. У нього відразу прокинеться совість. I зникнуть чари пана Морока, пропаде дія соку рослини-дорослини. I він перестане бути вражою силою, знову повернеться у дитинство» [6, с. 253-254].

Мотив дзеркала обіграно Вал. Шевчуком у казці “Чотири сестри”. Білокоса, Зеленокоса, Синьокоса й Золотокоса - чотири сестри, котрі щороку змінюють одна одну на царському троні, по черзі владарюючи у світі. Прокидаючись від сну напередодні свого правління, кожна із сестер дивиться на себе в дзеркало і чепуриться. Чорний Птах вирішив порушити звичний устрій і умовив Білокосу не поступатися місцем Весні. Він розбиває дзеркало й та не може побачити своє змарніле й постаріле обличчя після тривалого господарювання. Аби встановити звичний порядок у світі, сестри по черзі приходять до Білокосої і намагаються вмовити її поступитися місцем на троні. Вдається їм це завдяки своїй всепереможній любові, прагненням добра на світі. Дзеркало ж стає в цьому магічним помічником: 
“- А тепер на себе глянь, - сказала Золотокоса.

Вийняла дзеркальце й подала Зимі. Та зирнула - тихий зойк вирвався із грудей.

- Сестро моя, сестро! - закричала вона. - Що це за стара відьмуга на мене дивиться? Я не впізнаю себе!

- Зійди з трону, втомилася ти, - м'яко наказала Зимі сестра. - Піди в палаи, збуди Зеленокосу, впади до ї̈ ніг і попроси вибачення...» [10, с. 36]. За його допомогою відновлюється гармонія й рівновага у світі.

Дзеркало чарівника Діодора Аристарховича у повісті-казці I. Жиленко «Новорічна історія про двері, яких нема, і про те, як іноді корисно помилятися номером» наділене магічними властивостями. Натискаючи на чарівні кнопки на ньому, можна переміщатися в часі $і$ просторі. Орися, головна героїня твору, бачить у дзеркалі колись викинуті на смітник свої старі іграшки, підготовку до Нового року калинових чоловічків (виготовлення підковок на щастя, свічок, золочення горіхів), свою матусю, коли та була ще дівчинкою.

Ефектом дзеркальності наділене i скляне яйце 3 крихітною хаткою i засніженими ялинками всередині - загублена дитяча іграшка Орисиної мами. Знайшовши цей символ пам'яті, у жінки зринають спогади про поруйноване війною дитинство, вона мріє опинитись хоча б на мить у такій хатинці серед лісу, абстрагувавшись від чвар і недобрих слів, читати добрі розумні книги i слухати тишу.

I. Жиленко засобом мотиву дзеркальності діалогізує 3 читачем щодо питань доброти, милосердя, гармонії, що симптоматично для еволюції естетичної свідомості другої половини $\mathrm{XX}$ ст. духовна енергетика якої заглиблена в душу людини, повноту людського буття, його світла й добра. Зовнішній і внутрішній дискурси твору, апеляція до умовності, поглиблений психологізм, лірична тональність увиразнюють авторську свідомість, свідчать про оригінальність підходів щодо осмислення онтологічних проблем.

Казка (і фольклорна, і літературна) тяжіє до використання мотиву сну. Сон часто співвідноситься зі смертю персонажа (наприклад, у німецьких казках 
«Білосніжка» і «Спляча красуня» героїні засинають мертвим сном і оживають від поцілунку нареченого. Такими ж є богатирський сон героя після двобою, а також формули на кшталт «як же довго я спав». Детально про це: див. [11]. В. Пропп мовить про «випробування сном» у народній казці й пересторогу «Не засни», що зустрічається у фольклорі різних народів світу [4, с. 80-82].

У повісті-казці «В Країні Місячних Зайчиків» В. Нестайка мотив сну використано з метою введення героїні в ірреальний світ. Автор вдався до використання монтажної форми композиції: початок i кінець твору реалістична розповідь про дівчинку, основна частина - казка, що трапилась із Ганнусею уві сні. Тут вона подорожує до Країни Місячних Зайчиків, перебуває у темному лісі, спілкується із гномом, Спиридоном Спиридоновичем Красношапкою та ін.

У казці Вал. Шевчука «Місто без квітів» мотив сну автором використано двічі. Перший репрезентує авторську утопічну модель соціуму [див. про це: 12], альтернативного сьогоденню. Кольоровий сон дівчаток спонукає головних героїнь до подорожі за стінами свого міста у пошуках досконалішого світу. Там вони познайомилися 3 його доглядачами й охоронцями: Зеленою Бабусею або Матір'ю трави, іiі сестрою ДеревинкоюЛісовичкою та Матір'ю квітів, заклопотаних піклуванням про зело, насіння, лісову й садову деревину, про світ різнобарв’я, без якого неможливе щастя життя. Із насінням трави, квітів і дерев дівчатка повертаються від них до свого сірого міста. Від утоми вони засинають, і засинає все місто: «Була то ніч величезного сну - не залишилось у місті жодної людини, котра б не спала. Заснув навіть дід, який узагалі вночі не спав, а в кожному місті завжди такий дід живе. Заснула й королева, яку перед тим тиждень мучило неспання <...> Отак усі позасинали, через цее ніхто й не бачив, щзо вдіялося тієї ночі у місті» [10, с. 58-59]. Ранком, коли всі прокинулись, у місті стало повно різнокольорових квітів, соковитої трави, квітучих дерев, а Королева стала веселою, гарною й доброю жінкою. Мотив сну, таким чином, реалізує мрію головних героӥнь казки. 
У «Панні квітів» Вал. Шевчука Зеленоочка посилає на поле свій Сон, аби той розгадав таємницю учиненого над квітами чаклунства. «A Сон вийшов 3 грудей Зеленоочки й пішов на довгих тонких ногах, і за ним на так само довгих та тонких ногах подибав Димко, і йили вони так, одновимірно похитуючись, а прийшли звісно куди - на оте поле, чудне й жовте» [10, с. 117]. На полі жовтих мовчазних тюльпанів Сон дізнається від Димка, що насправді то є нещасні скорботні люди, яких Крінос перетворив на квіти, аби вони не страждали. Промовистим постає діалог Сну з Вужем: «Ці тюльпани і справді гарні. I поле цุе таки чудове, але я хочу запитати в тебе щуе одне, Вуже... <...> Але чи вони, цуі люди, - розпачливо вигукнув Сон Зеленоочки, - хотіли стати тюльпанами?» [10, с. 118]. Мотив сну тут підпорядкований осмисленню головною героӥнею важливої проблеми права людського вибору, що ініціює подальший розвиток казкових подій: протистояння з Кріносом, перемога Зеленоочки, розчаклування жовтих тюльпанів і перетворення їх на людей.

Сон у «Вертепі Маленького Хлопчика» Ігоря Калинця - сnосіб реалізаціï бажання головного героя. Малий з нетерпінням чекає телефонних дзвінків від батьків, які знаходяться у Португалії на заробітках, мріє швидше зустрітися 3 ними. У Різдвяну ніч, перетворившись на маленького Янголятка, головний герой разом із чарівним помічником, Ангелом-охоронцем, рушає до далекої країни відвідати батьків. Він приходить до матусі уві сні, батько бачить видиво за вікном нічного потягу, яким повертався до Сантарену. Світ казки, таким чином, накладається на світ реальності. Цей синтез дає можливість автору зробити акцент на вічних цінностях, що $є$ сенсом життя, - любові, доброті, теплих родинних стосунках.

Якщо у «Вертепі Маленького Хлопчика» мотив сну поєднано 3 мотивом подорожі / переміщення у просторі, то в казці на історичну тему «Данка і Крак» Ігор Калинець мотив сну синтезує 3 мотивом подорожі / переміщення в часі: «Просто ти у сні прибула у той час, коли щуе були козаки $i$ попри Львів протікала ияя річка (Полтва - В. К.). Але, коли ти вранці прокинешся, все знову буде так, як було вчора: тільки козацька чайка у гаю на колесах, бо інакше ї̈ не 
перевезеш по безводному Львові, стоятиме у Шевченківському гаю» [13, с. 50]. Данка в такий спосіб реагує на події, що відбуваються 3 нею в умовній реальності (знайомство із Краком, його розповіді про історичних постатей Львова і події, що відбувалися тут у давноминулі часи, історія Купер'яна), відображає пережиті нею емоції / хвилювання в оніричній формі.

Мотив сну у різдвяній казці Галини Рис «Чому усміхаються ангели» використано письменницею як засіб комунікащії умовно реалістичного персонажа з Янголом, як засіб його самопізнання. Ялинкова іграшка, Огірок, постійно була незадоволена (спочатку своєю самотністю, згодом своїм розташуванням на новорічній ялинці), заздрила Ангелу й хотіла зайняти його місце на ялинці. Ангел приходив до Огірка уві сні й розмовляв 3 ним. У цих діалогах - потужний моральний потенціал твору. «Огірки в цьому світі потрібні так само, як і бджолині стільники, морські камінці та соняшникове насіння. Без них світ не був би таким чудовим, яким він є» [14, с. 29]. Узагальнення, що звучать наприкінці твору («Хіба ж ти досі не відчув, що бути собою - це велике щастя?»), надають йому притчевої тональності, а філософський підтекст дає підстави говорити про подвійну адресацію (діти й дорослі).

Як бачимо, мотиви сну та дзеркала $є$ досить поширеними в українській літературній казці другої половини XX - початку XXI століття, повторюваними як у межах творчого доробку окремого автора (В. Нестайко, Ігор Калинець, Вал. Шевчук), так і текстах, дистанційованих часом, стилем, жанроформою. Маючи міфологічну й фольклорну природу, вони динамічні за своєю природою, мають важливе смислове навантаження (осмислення проблеми права людського вибору, гармонії й рівноваги у світі, самопізнання героя твору тощо), увиразнюють ціннісні орієнтири письменника. Наведений аналіз засвідчив конотативне багатство мотивів дзеркала і сну у площині авторської казки другої половини XX - початку XXI століття, їхню продуктивність щодо репрезентації авторського бачення філософсько-естетичних проблем, діалогу довкола важливих онтологічних питань. У казковому тексті мотиви стають 
актуалізатором його глибинної структури, посилюють символічний зміст, забезпечують кількаплощинність тексту.

\section{Література}

1. Теория литературы : в 2 т. : учеб. пособие : для студентов высш. учеб. заведений по специальности “Филология” / под ред. Н. Д. Тамарченко. - 4-е изд., стер. - М. : Академия, 2010. - Т. 1 : Теория художественного дискурса. Теоретическая поэтика / Н. Д. Тамарченко, В. И. Тюпа, С. Н. Бройтман. 2010. - 509, [1] c.

2. Грушевський М.С. Історія української літератури : в 6 т., 9 кн. / Михайло Грушевський ; [упоряд. В. В. Яременко ; авт. передм. П. П. Кононенко ; приміт. Л. Ф. Дунаєвської]. - К. : Либідь, 1993. - Т. І. - 392 с.

3. Карпенко С. Д. Міфологічні мотиви в українських народних казках про тварин. - автореф. дис. на здоб. наук. ступеня канд. філол. наук : спец. 10.01 .07 “Фольклористика” / С. Д. Карпенко. - К., Київський національний університет імені Тараса Шевченка, 2005. - 21 с.

4. Пропп В. Я. Морфология сказки / В. Я. Пропп. - Изд. 2-е. - Москва : Наука, 1969. - 168 с.

5. Веселовский А. Н. Историческая поэтика / А. Н. Веселовский ; ред., вступ. ст. и примеч. В. М. Жирмунского. - 4-е изд. - М. : Изд-во ЛКИ, 2010. 648 c.

6. Нестайко В. 3. Країна Сонячних Зайчиків : казкові повісті / В. 3. Нестайко. - К. : Країна Мрій, 2010. - 352 с.

7. Силантьев И. В. Сюжетологические исследования / И. В. Силантьев. М. : Языки славянской культуры, 2009. - 224 с. - (Коммуникативные стратегии культуры).

8. Золян С. Т. “Свет мой, зеркальце, скажи” (К семиотике волшебного зеркала) / С. Т. Золян // Учёные записки Тартуского государственного университета. Вып. 831. Труды по знаковым системам. - Тарту, 1988. C. $32-41$. 
9. Колотова О. О. Мотиви “дзеркала” і “задзеркалля” як моделі тут-буття і там-буття в художніх відображеннях картини світу [Електронний ресурс] / O. О. Колотова. - Режим доступу : http://www.nbuv.gov.ua/portal/Soc_Gum/ Vdakk/2011_4/11.pdf. - Назва з екрана. - Дата звернення : 15.11.11.

10.Шевчук В. Панна квітів : казки моїх дочок / Валерій Шевчук. - К. : Веселка, 1990. - 184 с.

11.Наумовська О. Онірична семантика простору смерті у фольклорі в контексті дискретності історичного тіла [Електронний ресурс]. - Режим доступу : http://philology.knu.ua/files/library/folklore/37-2/7.pdf. - Назва 3 екрана. - Дата звернення : 05.04.16.

12.Кизилова В. В. Мотив сну в казках В. Шевчука збірки "Панна квітів": типологія, функції / В. Кизилова // Науковий вісник Міжнародного гуманітарного університету. Серія : Філологія [зб. наук. праць]. - Одеса, 2016. Вип. 21. - Т. 1 - С. 13-16.

13.Калинець Ігор. Данка і Крак / Ігор Калинець. - Львів : ЛА “Піраміда”, 2009. -92 c.

14.Рис Галина. Чому усміхаються ангели / Галина Рис // Зимові історії для дітей. Твори українських письменників. - Львів, 2011. - С. 26-30. 